\title{
Reflections on COVID-19 and my First Dietetic Internship Experience
}

Kelsey Gill, Dietetic Intern, Integrated Dietetic Internship Program, St Francis Xavier University

The town came to a sudden halt in March 2020. Students were told to pack their bags and head home as soon as they could. Classes were put on pause while professors tried to navigate the world of online teaching and staff across the St. Francis Xavier University campus were told they would be working from home until further notice. Fast forward to July and the university's announcement to re-open campus to students in September. There was uproar at first by students, staff, community members, alumni, and just about anyone who heard about it. Panic filled the minds of many - how would the university ensure a safe return of their students when some were traveling from large cities, where Covid cases were steadily increasing? How would the university protect the small Nova Scotian town its nestled in?

These concerns were acknowledged via virtual town hall forums and communication between the town, the university and its students, which enabled the creation of a plan to re-open the university. Students entering from outside of Atlantic Canada were required to isolate for two weeks upon arrival in town. Students could choose to isolate with family/friends if able to do so; if this wasn't possible students were required to isolate in one of the 12 university housing buildings. This need to selfisolate posed a number of unique challenges in of itself - how would students get food? What would happen if a student upon arrival or within their 14 days exhibited symptoms of Covid-19? The university decided upon mandatory covid-19 testing for all students entering Antigonish; students were required to be tested upon arrival, one week into isolation, and on their last day of isolation. Following their two-week isolation period students were given green bracelets that were to be worn the entire month of September; this bracelet was meant to identify students who had completed their isolation and were deemed healthy. As for the matter of food, students were delivered three meals a day to their dorm room to prevent large gatherings in meal hall and the potential for the spread of the Covid-19 virus. This required foodservice staff to work around the clock, prepping cold ingredients and meals a day in advance. Each meal consisted of the main course, a side item such as a salad, a dessert option, multiple beverage options, and additional snacks for students to consume between meal periods.

I started my dietetic internship placement with campus food service in the midst of this "isolationmeal period' and was able to not only participate in the meal production and delivery system firsthand, but also contribute to improvement and quality control initiatives. I think it is safe to say that my first week of practicum was far from conventional. From the minute I entered the kitchen Monday morning to the second I left on Saturday evening, I was going non-stop. But while the kitchen was running at full capacity, every time I stepped outside it felt like I was in a ghost town. There were no students on the streets and the smiles of staff members were hidden behind masks. Similarly, off campus and around town, residents seemed onedge, as if they were waiting for a case of Covid-19 to be announced. While I had spent my summer in town, many community members weren't aware of this and I 
noticed them acting differently around me. I knew many were wondering 'who is this? Where is she from? Has she isolated? Is she feeling sick?' Questions that I too caught myself wondering about other young adults/ potential students.

My concerns dissipated when I was working in the kitchen. There wasn't time to worry about whether or not someone was feeling 100\% or if they came in contact with someone with Covid-19. We had to focus on feeding close to 500 students and focusing on what we could do to ensure they were receiving safe and nutritious food. I was responsible for a number of daily tasks, such as typing up the menu and making a master allergy list outlining what common allergens were found in the various menu items and labelling the containers for students with dietary restrictions so they would receive modified menu items that would meet their nutritional, physical and cultural needs. I was also responsible for counting out 500 utensils and containers for each meal and separating them by residence to ensure every building got the right amount of meals and no student went hungry. Finally, at the end of every day I would join the assembly line and load the meals into the hot boxes and into the van, double checking meals that had a sticker noting a dietary restriction. While this kept me busy all week, I must admit that many of the tasks I was given seemed repetitive. I had imagined my internship involving strategic thinking, and high level operations and here I was packing boxes and checking stickers.

I initially wondered about the value of what I was doing, however, when my preceptor asked me to come in on the weekend, I realized the importance of my job. It was then that I recognized that without someone like me doing the work, the operation would be halted. Without the containers counted the kitchen staff would have be tasked with the challenge of plating as many dishes as possible, with no indicator of whether or not enough meals were prepared. Similarly, if I didn't label the containers or outline which menu items contained allergens, students with dietary restrictions would be put at risk. Doing these jobs has provided me with a newfound respect for all the food service employees, whether they be a chef, a dishwasher, a van driver, or a utility worker. I realize that all of these jobs are critical to the overall success of the operation.

My final and perhaps most important insight was the lack of recognition of the valuable role played by the 'behind the scenes' kitchen staff. Over these last nine months I have witnessed front-line workers, like nurses, doctors, and long-term care staff being praised for their hard work during the pandemic. While this respect is well-earned, we must not forget about the other professions that have worked tirelessly throughout this pandemic in hopes of maintaining some sense of normalcy. Many of the kitchen-staff were working long hours, seven days a week but they didn't get the same recognition as healthcare professionals; perhaps it was because the work they complete is hidden in the kitchen. I came to realize however that without them the students wouldn't have been able to return to StFX and safely isolate. Without the kitchen staff the students wouldn't have had full-course meals delivered to their doors three times a day.

While it wasn't how I expected the start of my internship to commence, I realize now that all jobs contribute to a complex system. Furthermore, I have come to learn that the foodservice industry is not isolated. It impacts many other aspects of society because as humans we need to eat to survive. As a future dietitian I am left wondering what long-lasting impacts Covid-19 will have on our food system and what my role will be.

\section{Author Bio:}

Kelsey Gill recently graduated with a Bachelor of Science in Human Nutrition and is currently completing the Integrated Dietetic Internship program at St. Francis Xavier University. Originally from New Brunswick, Kelsey hopes to pursue a career focused in sports nutrition and eventually launch her own private practice. 